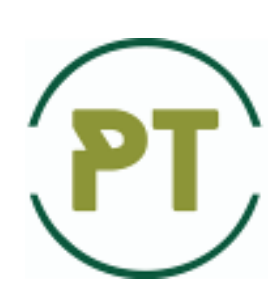

\title{
Problems of Tribology
}

Website: http://tribology.khnu.km.ua/index.php/ProbTrib

E-mail: tribosenator@gmail.com

DOI: https://doi.org/10.31891/2079-1372-2021-101-3-81-88

\section{Influence of lubrication on the friction and wear of car rolling bearings}

\author{
O. Dykha*, O. Makovkin, S. Posonsky \\ ${ }^{l}$ Khmelnitskyi National University, Ukraine \\ *E-mail: tribosenator@gmail.com
}

Received: 10 July 2021: Revised: 30 August: Accept: 25 September 2021

\begin{abstract}
The goal of the work is to develop computational and experimental approaches to determine the wear resistance of friction units with internal contact of cylinders with slip. The scientific novelty consists in taking into account the slip for calculating the friction path and the wear of the cylinders with internal contact and the proposed method for identifying the parameters of the wear law based on the test results. Practical value is the proposed methods to account load, slip and lubrication conditions on the resource for the design of friction units. The dependences for determining the friction path for internal rolling of cylinders have been considered. The design of an experimental setup for studying friction and wear of cylinders with slip has been proposed. Experimental studies have been carried out: paths of friction; wear of surfaces both with a key and without a key; the effect of lubricants on wear has been studied. The form of the wear model is proposed to determine the effectiveness of methods for increasing wear resistance. The method for determining the parameters of the wear law has been implemented based on the test results. The results show the efficiency of copper powder as an additive to a lubricant. It has been established that the wear of cylinders with a key is greater than the wear of cylinders without a key due to different friction paths. A practical example of determining the wear of a car hub shaft using the wear patterns is presented.
\end{abstract}

Keywords: Friction Pair, Bearing, Wear Parameters, Lubrication, Additive, Suspension Hub, Laboratory Test

\section{Introduction}

Most of the contact conditions for machine parts are internal or external cylinder contact. The internal contact of the cylindrical parts of the shaft and the hole can be either with a gap or with an interference fit. In this paper, machine units are considered in which a solid cylinder contact with a hollow cylinder in a different fit and the surfaces of the cylinders roll over each other with slipping. Such machine units include: the connection of the rolling bearing rings with the shaft; key connections; wave transmission; contact in needle bearings. The types and mechanisms of wear of cylindrical couplings operating in rolling conditions with slip are common. The friction path may be small for small gaps and large enough for large gaps. In the case of a small friction path surface damage is observed in the form of fretting corrosion. In the case of a long and continuous friction path, normal wear is observed. The definition of contact pressures is based on the contact mechanics of contact surfaces. At the same time, not enough attention is paid to methods for determining the friction path or the magnitude of slip in contact. The goal of the work is to develop computational and experimental approaches to determine the wear resistance of friction units with internal contact of cylinders with slip. In this study, it is proposed to take into account the slip values when calculating the actual friction path and the total wear of the cylinders with internal contact and the proposed method for identifying the parameters of the wear law based on the results of laboratory tests. The proposed approaches make it possible to determine the effect of load, slip and lubrication conditions on the durability of the friction unit by the wear criterion.

\section{Literature review}

Much attention is paid to the study the problems of rolling friction in cylindrical tribosystems. Thus, in [1] the effect of rolling resistance force, sample rotation speed and loading on wear is investigated. A mathematical model has been obtained that makes it possible to predict the wear of a friction pair under rolling 
friction conditions. The papers [2-3] study the role of the slip coefficient in the development of cracks and fatigue life of rail materials. The results show that the slip coefficient has an important influence on the wear of materials. The article [4] presents models for calculating the speed of the rollers of a cylindrical roller bearing. It was found that the slip of rollers depends on the bearing design, load, shaft speed, lubricant properties and temperature. In [5] on the basis of dynamic analysis of rolling bearings, differential equations of a cylindrical roller bearing are established. The influence of relative slip, sliding friction coefficients and residual stresses on the distribution of shear stresses are analyzed in paper [6]. In article [7] a bearing with turbulent lubrication is considered. The simulation results are in good agreement with the experimental data. In [8] it is noted that the powder lubricants are effective, despite the increased friction indicators compared to liquid oils. This article [9] provides an equation for calculating the frictional moment of a dry lubricated tapered roller bearing, which takes into account the misalignment of the rollers. A torque model to optimize bearing design has been developed. The papers [10-13] consider the modeling of friction and wear during rolling with slip. Thus Numerical simulation of single surface irregularities passing through lubricated rolling contacts during sliding is carried out in [10]. Phenomena have been found to explain how the roughness moves through the contact and lubricates it by sliding. In [11-12] new models of rolling bearing durability are proposed. Load capacity equations have been written for both point and line contacts. The value of the empirical constant of the ball bearing has been determined based on the regression analysis of the experimental data. In the article [13], a method for determining the equivalent stiffness for bearing devices with self-elimination of the gap has been implemented. In addition, a linear model has been proposed, taking into account the effect of contact on the vibration mode and rotor frequency. Simulations and experiments have been performed to test the effectiveness of the stiffness identification method. In works [14-15] models of bearing wear are proposed and methods of identifying the parameters of these models are described.

Thus, the determination of the amount of slip during rolling of cylinders is one of the important problems of contact mechanics and tribology in general. Without knowing the amount of slip, it is impossible to simulate the wear of rolling bearings. Known studies have not provided a calculation method for assessing the amount of slip during cylinder contact. Taking this into account, the only correct thing is to determine the slip value only experimentally.

\section{Methodology for investigating slip with internal cylinder contact}

The problem of describing the rolling slip process is one of the most difficult in contact mechanics. Note that almost all variants of rolling mechanisms relate to external contact of cylinders or balls. Let us consider the case of internal rolling of cylinders that are not connected to each other in the tangential direction (Fig. 1a).

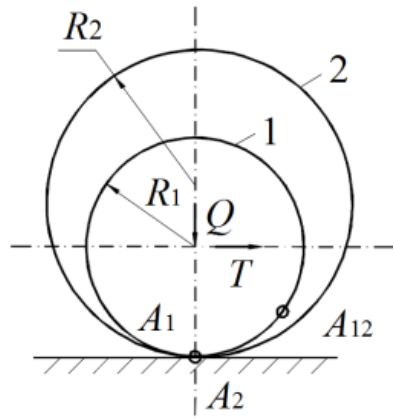

Fig. 1. Cylinder contact during rolling

Under the action of the forces $Q$ and $T$, the outer cylinder rolls along a plane. At this time, the inner cylinder with its outer surface of radius $R_{1}$ rolls along the inner surface of radius $R_{2}$ of the outer cylinder. Let the outer cylinder, when rolling, make a full revolution $\varphi=2 \pi$ and point $A_{2}$ returned to its original position, having passed the path $S_{2}=2 \pi R_{2}$. During this time, the inner cylinder, when rolling along the inner surface of the outer cylinder, will travel the path $S_{1}=2 \pi R$ and will not return to the starting position $A_{1}$. In this case, the point $A_{1}$ will not reach the initial position by the amount of the path length $\Delta S$ :

$$
\Delta s=2 \pi R_{2}-2 \pi R_{1}=2 \pi \Delta
$$

Next, we consider the conjugation with the gap $\Delta$ of the shaft of radius $R_{1}$ and hollow cylinder of radius $R_{2}$, connected by internal gearing with the number of teeth $z$ (Fig. $1 b$ ). When the cylinders are rolling internally, the teeth prevent the cylinders from sliding as in free rolling. The friction path is distributed between the teeth. When turning one tooth, the slip will be by the value:

$$
s_{1}=2 \pi \Delta / z
$$


With internal rolling of the shaft over a hollow cylinder, connected by a key. This connection is similar to the sliding of the teeth at $z=1: s_{k}=2 \pi \Delta$. Note that formulas (1-2) determine the total amount of slip in the considered rolling section. In fact, there is continuous sliding throughout the entire section. Thus, it has been found that the main role for the type and value of slippage of the coupled cylinders is played by the gap between the shaft and the hollow cylinders.

In some cases, cylinders or shafts in machines rotate, and their surfaces roll over each other. As mentioned above, there are two possible cases: the inner and outer cylinders are connected by a key or pin type device; the cylinders are not connected in the circumferential direction and roll freely over each other. It is known that both in one and in the other cases, the interaction of the cylinders is worn out. Let us consider the method of testing for wear and identification of the laws of wear with internal contact of the cylinders. Experimental studies were carried out on a setup, the design of which is shown in Fig. 2.

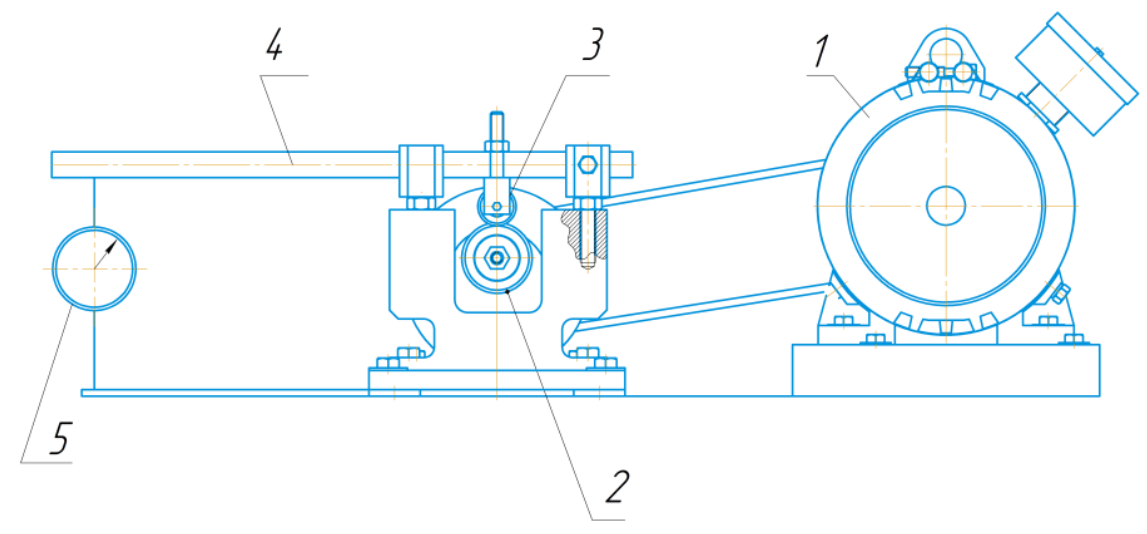

Fig. 2. Experimental setup

On the basis of the installation are located: engine 1 and working unit 2, interconnected by a V-belt transmission. The load is transmitted through the bearing 3 by means of a lever 4 . The the load is controlled by an indicator 5. The tests were carried out for two schemes of internal contact of the cylinders: connecting the cylinders with a key and without a key (Fig.3).

Ring 4 (52100 steel) was put on the bushing 2 (1045 steel) and fixed with a pin 3 (Fig.3a). The connected parts were mounted on the shaft 1 and fixed with nut 5 . Using a ball $R=2.67 \mathrm{~mm}$, a hole was pressed on the outer side of the sleeve 2 to register the amount of sleeve wear. An IZA-2 optical device was used to measure the indentation diameter $d$. The indentation depth was determined by the formula:

$$
h=d^{2} / 2 R \text {. }
$$

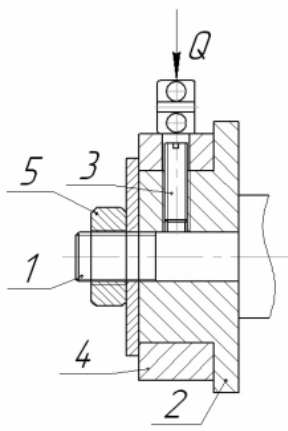

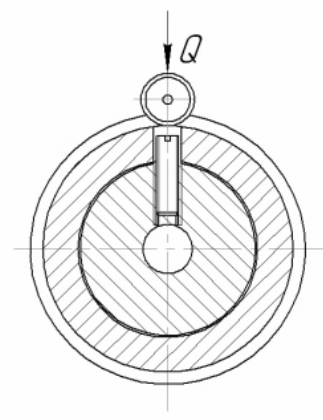

a

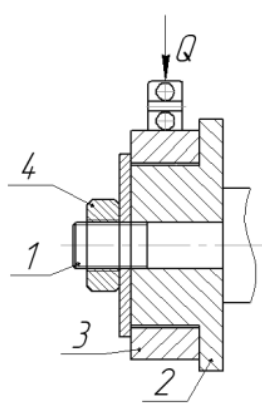

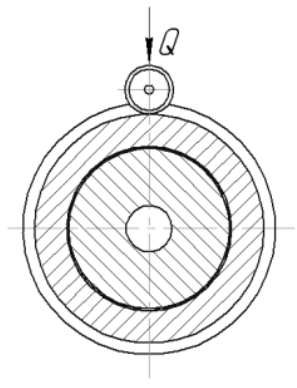

Fig. 3. Working unit of the installation: $a$ - with a key; $b$-without key

The difference between the initial indentation depth $h_{0}$ and the indentation depth after testing was taken to be equal to the linear wear of the sleeve surface $u_{\mathrm{W}}$. The friction path of two cylinders has been determined by the dependence:

$$
s_{1}=2 b n t,
$$

where $b$ is the contact strip half-width;

$n$ is the part rotation frequency;

$t$ is the time of testing. 
The dimensions of the contact area with internal contact of two cylinders according to the Hertz formula:

$$
b=1.128\left(\frac{Q}{l E} \frac{R_{1} R_{2}}{R_{2}-R_{1}}\right)^{1 / 2}
$$

where $Q$ is the part load;

$R_{1}$ is the outer radius of the sleeve;

$R_{2}$ is the inner radius of the ring;

$l$ is the sleeve width;

$E$ is the modulus of elasticity of the bushing material.

The tests were carried out at two loads of $100 \mathrm{~N}$ and $200 \mathrm{~N}$. To study the effect of a lubricant on wear, three lubrication modes were used: dry contact; Fiol-3; Fiol-3 with copper powder additives (1\% by weight). The results of tests for a load of $100 \mathrm{~N}$ without lubricant are shown in Table 1 . The tests were carried out with the following initial data: $\mathrm{R}=2.67 \mathrm{~mm} ; n=650 \mathrm{rev}^{-1} ; R_{1}=35 \mathrm{~mm} ; R_{2}=35.5 \mathrm{~mm} ; \Delta=0.5 \mathrm{~mm}$.

Test results without lubrication at a load of $100 \mathrm{~N}$

Table 1

\begin{tabular}{|c|c|c|c|c|}
\hline$t, \mathrm{~min}$ & $d, \mathrm{~mm}$ & $h, \mathrm{~mm}$ & $u_{\mathrm{w}}, \mathrm{mm}$ & $S, \mathrm{~mm} \cdot 10^{5}$ \\
\hline- & 1.929 & 0.20 & - & - \\
\hline 100 & 1.83 & 0.159 & 0.008 & 0.3 \\
\hline 200 & 1.85 & 0.155 & 0.012 & 0.6 \\
\hline 300 & 1.83 & 0.152 & 0.015 & 0.9 \\
\hline 600 & 1.79 & 0.15 & 0.02 & 1.8 \\
\hline 900 & 1.75 & 0.144 & 0.025 & 2.5 \\
\hline
\end{tabular}

The results have been obtained similarly for different modes of lubrication and loading. The dependence of wear on the friction path conditions is shown in Fig. $4(\mathrm{Q}=100 \mathrm{~N})$.

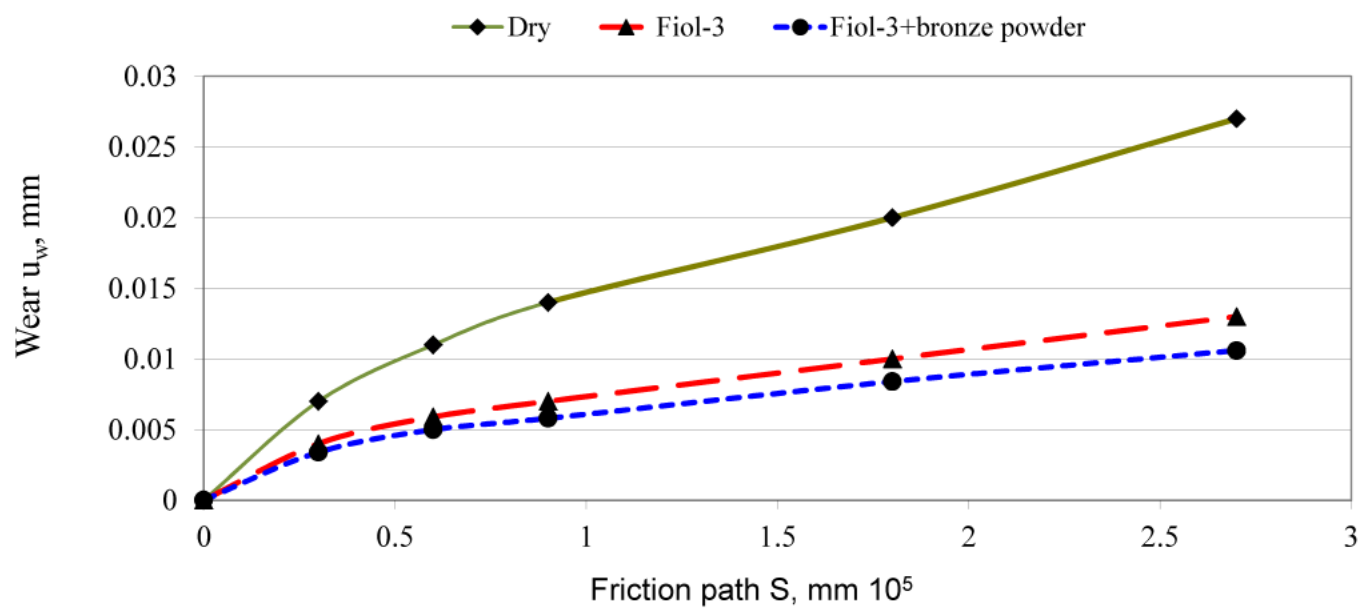

Fig. 4. Wear on the friction path with non-free contact of the cylinders $(Q=100 \mathrm{~N})$

Wear tests with free contact of the cylinders were carried out according to the scheme in Fig. $3 \mathrm{~b}$ also for two loads and three modes of contact lubrication.

The tests were carried out with the initial data: $\mathrm{R}=2.67 \mathrm{~mm} ; n=650 \mathrm{rev}^{-1} ; R_{1}=34.7 \mathrm{~mm} ; R_{2}=35.7 \mathrm{~mm}$; $\Delta=1 \mathrm{~mm}$. The wear on the friction path with free contact of the cylinders for various lubrication conditions is shown in Fig. $5(Q=100 \mathrm{~N})$. 


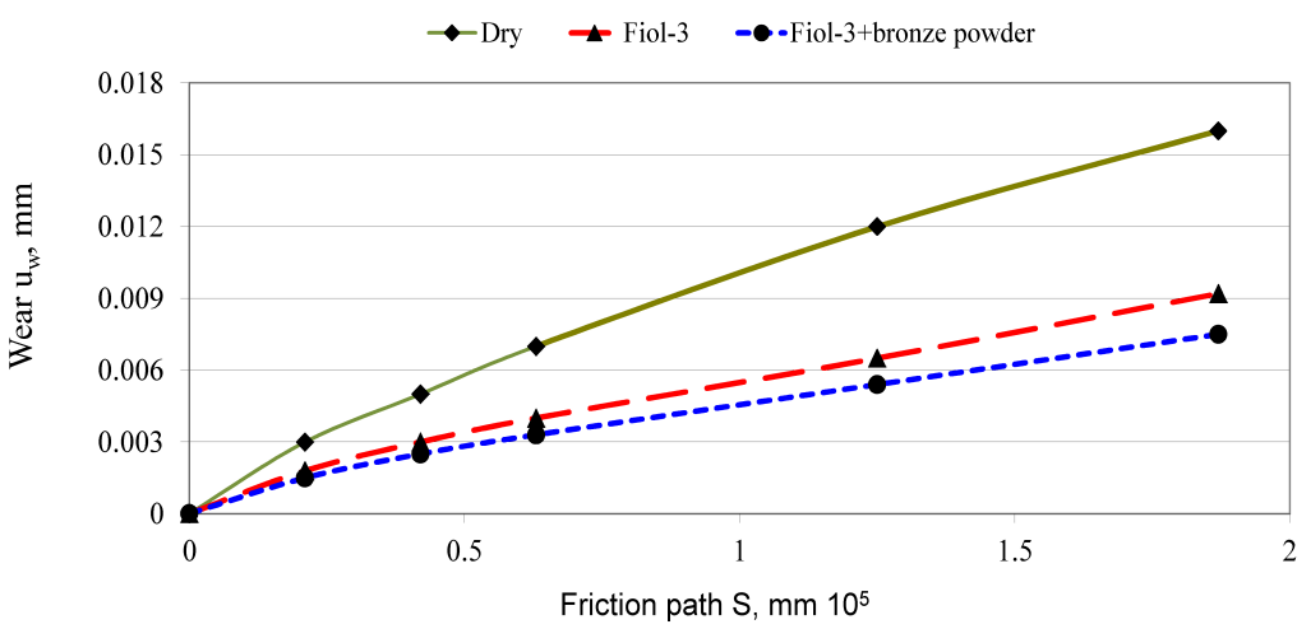

Fig. 5. Dependences of wear on the friction path with free contact of the cylinders $(Q=100 \mathrm{~N})$

Results of estimated wear resistance at internal contact of cylinders with slip

For the analysis of the wear of machine parts, you can use a simple wear model:

$$
u_{w}=k_{w} \sigma^{m} S \text {, }
$$

where $u_{\mathrm{w}}$ is the current wear;

$k_{\mathrm{w}}, m$ are the parameters of the wear model determined from the experiment; $\sigma$ is the contact pressure;

$S$ is the friction path at wear points, determined by calculation or from experiment.

To determine the parameters of the wear law (6), it is proposed to use the obtained results of tests for cylinder wear under various lubrication modes. The wear law parameter $\mathrm{m}$ is determined by the results of the wear values and contact pressures obtained at two values of the external load: $100 \mathrm{~N}$ and $200 \mathrm{~N}$ according to the dependence:

$$
m=\frac{\lg \left(u_{w 1} / u_{w 2}\right)}{\lg \left(\sigma_{1} / \sigma_{2}\right)},
$$

where $\Delta u_{\mathrm{w} 1}, \Delta u_{\mathrm{w} 2}$ are the values of the wear of the part at various loads $Q$;

$\sigma$ is the maximum contact pressure at a given load according to the Hertz formula:

$$
\sigma=0.418\left(\frac{Q E}{l} \frac{R_{2}-R_{1}}{R_{1} R_{2}}\right)^{1 / 2},
$$

Wear model parameter $k_{\mathrm{w}}$ :

$$
k_{w}=\frac{u_{w 2}}{\sigma^{m_{2}} S_{2}} .
$$

The results of wear tests and parameters of the law of wear of cylinders for various lubrication conditions are presented in Table 2 .

Results of studies of cylinders wear with slip

\begin{tabular}{|l|l|l|l|l|l|l|}
\hline \multirow{2}{*}{ Lubricant } & \multicolumn{3}{|l|}{ With key } & \multicolumn{2}{l|}{ Without key } \\
\cline { 2 - 7 } & Dry & Fiol-3 & $\begin{array}{l}\text { Fiol-3 } \\
+ \text { bronze }\end{array}$ & Dry & Fiol-3 & $\begin{array}{l}\text { Fiol-3 } \\
+ \text { bronze }\end{array}$ \\
\hline$b(100 N), \mathrm{mm}$ & 0.23 & 0.23 & 0.23 & 0.16 & 0.16 & 0.16 \\
\hline$b(200 N), \mathrm{mm}$ & 0.32 & 0.32 & 0.32 & 0.23 & 0.23 & 0.23 \\
\hline$S_{900}(100 N), \mathrm{mm} \cdot 10^{5}$ & 2.7 & 2.7 & 2.7 & 1.87 & 1.87 & 1.87 \\
\hline$S_{900}(200 N), \mathrm{mm} \cdot 10^{5}$ & 3.75 & 3.75 & 3.75 & 2.7 & 2.7 & 2.7 \\
\hline$\sigma_{100}, \mathrm{MPa}$ & 15 & \multicolumn{7}{|l|}{} & 19.5 \\
\hline$\sigma_{200}, \mathrm{MPa}$ & 199 & \multicolumn{7}{|l|}{} & 285 & \\
\hline$m$ & 1.84 & 2 & 2.04 & 1.8 & 1.76 & 1.78 \\
\hline$K \mathrm{~W}, \mathrm{MPa}^{-1} \cdot 10^{-9}$ & 18.4 & 8.85 & 7.2 & 7.1 & 4.3 & 3.52 \\
\hline
\end{tabular}


Thus, in contrast to the known approaches, a theoretical and experimental method is proposed for determining the wear of cylinders with internal contact, taking into account the friction path from the slip value. A method for identifying the parameters of the wear law based on the results of laboratory tests is also proposed. For the further development of ideas about the mechanism of slip, it is necessary to carry out experiments to determine the slippage of uncoupled cylinders and to study experimentally the influence of interference and clearance on the amount of slippage and wear.

The task is to determine the wear of the hub shaft in the connection of the rolling ball bearing of the suspension hub of the vehicle. The initial data: load on one wheel is $3000 \mathrm{~N}$; diameter of the bearing ring is $\mathrm{d}=34$ $\mathrm{mm}$; ring thickness is $5 \mathrm{~mm}$; the clearance $\Delta=0.05 \mathrm{~mm}$. The slip in the contact is taken to be equal to the value of the relative clearance: $\psi=\Delta / \mathrm{R}=0.003$. The friction path in one wheel revolution: $\mathrm{S} 1=2 \pi \mathrm{R} \psi=0.32$. With a wheel diameter of $500 \mathrm{~mm}$, the wheel makes an 640 revolutions per $1 \mathrm{~km}$ of run. Then the friction path for $100,000 \mathrm{~km}$ of run will be: $\mathrm{S}=0.32 \cdot 640 \cdot 100,000=2.05 \cdot 107 \mathrm{~mm}$. The calculation of the hub shaft wear was carried out to the formula (7). Two modes of lubrication were considered: Fiol-3 and grease with copper powder. The parameters of the wear (7) were taken from Table 2. The contact pressure was taken to be $5 \mathrm{MPa}$. The results of calculating the wear of the hub shaft are shown in Fig. 6.

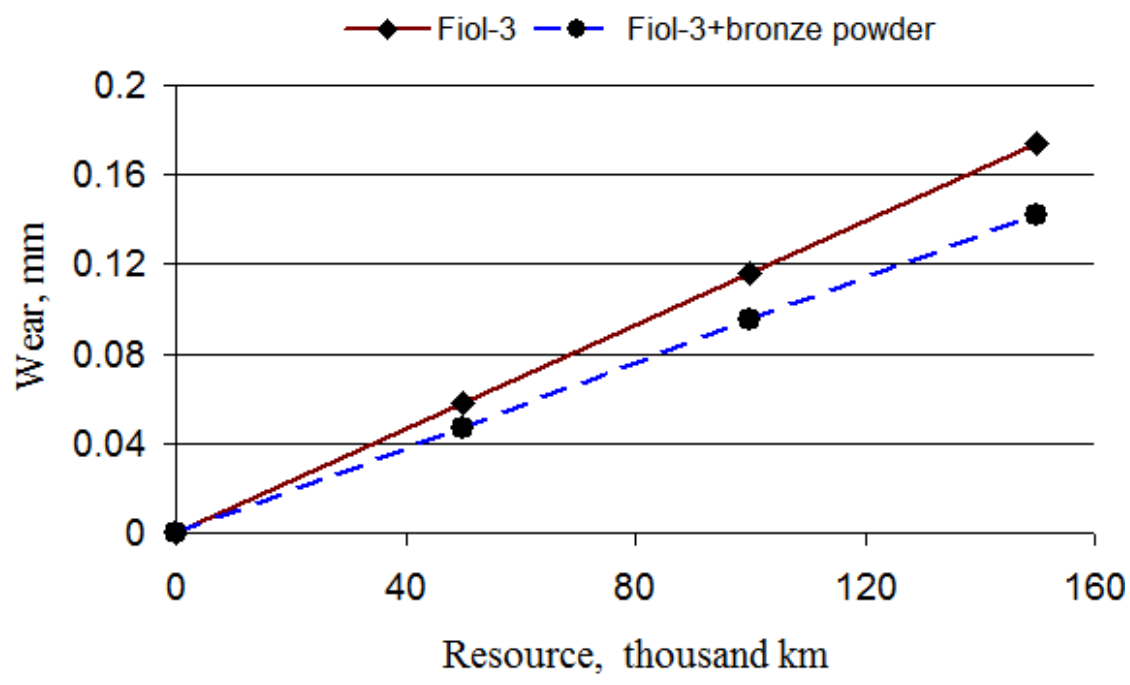

Fig. 6. Dependence of the hub shaft wear on the vehicle resource

The calculation results show the efficiency of using copper powder as an additive to a lubricant.

\section{Conclusions}

Developed a test procedure for wear during internal rolling of a cylinder.The developed technique is used to assess the effectiveness of lubricants and additives from bronze powder to increase the wear resistance of the interface. As a result of tests, it has been found that: wear of cylinders with a key is 1.35 times more than the wear of cylinders without a key, which is explained by a correspondingly large friction path; lubrication with Fiol reduces the wear of the joint by 1.81 times; lubrication with Fiol with the addition of bronze powder reduces wear in comparison with lubricant without the addition of additives by $1.2 \ldots 1.8$ times; the overall reduction in wear when using Fiol with bronze powder is estimated 2.3 ..2.1 times.

\section{References}

1. Korolev, A.V., Korolev, A.A. Friction machine for accelerated wear tests of frictional rolling elements. J. Frict. Wear 38, 77-81 (2017)

2. Ronen, S., Goltsberg, R. \& Etsion, I. A comparison of stick and slip contact conditions for a coated sphere compressed by a rigid flat. Friction 5, 326-338 (2017)

3. Wang, W.J., Lewis, S.R., Lewis, R., Beagles, A., He, C.G. The role of slip ratio in rolling contact fatigue of rail materials under wet conditions, Wear 376-377, 1892-1900 (2017)

4. Guo, Yi, Jonathan Keller,Validation of combined analytical methods to predict slip in cylindrical roller bearings.Tribology International 148, 106347 (2020)

5. Deng, S., Lu, Y., Zhang, W., Sun, X., Lu, Z. Cage slip characteristics of a cylindrical roller bearing with a trilobe-raceway. Chinese Journal of Aeronautics 31/2, 351-362 (2018)

6. Goryacheva, I.G., Torskaya, E.V. Modeling the Accumulation of Contact Fatigue Damage in Materials with Residual Stresses under Rolling Friction. J. Frict. Wear 40, 33-38 (2019)

7. Zhu, S., Sun, J., Li, B., Zhao, X., Zhu, G. Stochastic models for turbulent lubrication of bearing with rough surfaces. Tribology International 136, 224-233 (2019) 
8. Rahmani, F., Pandey, R.,. Dutt, J. Performance Studies of Powder-Lubricated Journal Bearing Having Different Pocket Shapes. J. Tribol 140(3), 031704, (2018)

9. Zhang, C., Gu, L., Mao, Y. et al. Modeling the frictional torque of a dry-lubricated tapered roller bearing considering the roller skewing. Friction 7, 551-563 (2019)

10. Everitt, C.-M., Alfredsson, B. Surface initiation of rolling contact fatigue at asperities considering slip, shear limit and thermal elastohydrodynamic lubrication. Tribology International 137, 76-93 (2019)

11. Xue, Y., Chen, J., Guo, S. et al. Finite element simulation and experimental test of the wear behavior for self-lubricating spherical plain bearings. Friction 6, 297-306 (2018)

12. Gupta, P., Zaretsky, E. New Stress-Based Fatigue Life Models for Ball and Roller Bearings. Tribology Transactions 61(2), 304-324 (2018)

13. Jin, C., Li, G., Hu, Y., Xu, Y. Xu, L. Identification of Mechanism Stiffness of Autoeliminating Clearance for Auxiliary Bearing. Tribology Transactions 62(2) (2019)

14. Dykha, A.,. Sorokatyi, R., Makovkin, O., Babak, O.. Calculation-Experimental Modeling of Wear of Cylindrical Sliding Bearings, Eastern-European Journal of Enterprise Technologies 5(1(89)), 51-59 (2017)

15. Aleksandr, D., Dmitry, M. Prediction the wear of sliding bearings. International Journal of Engineering \& Technology, 7 (2.23), 4-8 (2018). doi: https://doi.org/10.14419/ijet.v7i2.23.11872 
Диха О.В., Маковкін О.М., Посонський С.Ф. Вплив змащування на тертя та знос підшипників кочення автомобіля

Метою роботи $є$ розробка обчислювального та експериментального підходів для визначення зносостійкості агрегатів тертя з внутрішнім контактом циліндрів із ковзанням. Наукова новизна полягає у врахуванні ковзання для розрахунку шляху тертя та зносу циліндрів із внутрішнім контактом та запропонованого методу визначення параметрів закону зносу за результатами випробувань. Практичне значення мають запропоновані методи впливу навантаження, ковзання та умов змащення ресурсу для проектування агрегатів тертя. Розглянуто залежності для визначення шляху тертя для внутрішнього кочення циліндрів. Запропоновано конструкцію експериментальної установки для вивчення тертя та зносу циліндрів із ковзанням. Проведені експериментальні дослідження: шляху тертя; зносу поверхонь як із шпонкою, так і без шпонки; вивчено вплив мастильних матеріалів на знос. Форма моделі зносу пропонується для визначення ефективності методів підвищення зносостійкості. За результатами випробувань реалізовано метод визначення параметрів закону зносу. Результати показують ефективність мідного порошку як добавки до мастильного матеріалу. Встановлено, що знос циліндрів із ключем більший, ніж знос циліндрів без ключа через різні шляхи тертя. Наведено практичний приклад визначення зносу валу втулки автомобіля за допомогою шаблонів зносу.

Ключові слова: пара тертя, підшипник, параметри зносу, змащення, добавка, підвісна втулка, лабораторне випробування 